\title{
Implementasi Undang-Undang Nomor 23 Tahun 2004 tentang Penghapusan Kekerasan dalam Rumah Tangga di Kota Batam
}

\author{
Emilda Firdaus \\ Fakultas Hukum Universitas Riau \\ Jl. Patimura No.9 Pekanbaru \\ emilda27.ef@gmail.com
}

\begin{abstract}
The Law on Domestic Violence Eradication (UU PKDRT) is a government policy to protect the women rights. Up to recent the women of the domestic violence victims are shackled by an incorrect comprehension on religion and culture. This research studies the implementation of UU PKDRT in Batam City, the obstacles, and the preventive attempts. The research used sociological juridical by employing primary data. The result concludes that: first, the implementation of in Batam City is not yet maximum due to the lack of gender sensitivity of both the society and government of Batam; second, the obstacles of the implementation of UU PKDRT lays on the social cultural factor, in which the patriarchal culture still dominates the conventional mindset of the society and many of Batam people do not know UU PKDRT; and third, the attempts taken by the Batam government are through media campaign, socialization of UU PKDRT, and training on the prevention of violence through family education. Besides, the material on understandinggendermust be added in formal schooling to change the old perception existing in our society.
\end{abstract}

Key words : Implementation, domestic violence, human rights

\begin{abstract}
Abstrak
Undang-Undang Penghapusan Kekerasan Dalam Rumah Tangga (UU PKDRT) adalah suatu kebijakan pemerintah untuk melindungi hak-hak perempuan. Selama ini perempuan korban Kekerasan Dalam Rumah Tangga (KDRT) terbelenggu dengan pemahaman yang salah terhadap agama dan budaya. Penelitian ini mengkaji tentang implementasi UU PKDRT di Kota Batam, faktor-faktor penghambatnya, dan upaya pencegahannya. Penelitian ini menggunakan metode yuridis sosiologis dengan menggunakan data primer. Hasil penelitian menyimpulkan bahwa, Pertama: implementasi UU PKDRT di Kota Batam belum maksimal karena kurangnya kepekaan gender baik oleh masyarakat Batam maupun Pemerintah; Kedua, faktor penghambat implementasi UU PKDRT terletak pada faktor budaya masyarakat, yaitu pola fikir konvensional yang masih kuat dengan budaya patriakhi dan banyak masyarakat Batam yang tidak tahu tentang UU PKDRT. Ketiga, upaya yang dilakukan Pemerintah Kota Batam adalah melakukan kampanye media, sosialisasi UU PKDRT, dan mengadakan pelatihan pencegahan kekerasan melalui pendidikan keluarga. Selain itu, hendaknya ditambahkan materi tentang pemahaman gender pada jenjang pendidikan formal untuk merubah budaya masyarakat.
\end{abstract}

Kata kunci: Implementasi, kekerasan dalam rumah tangga, HAM 


\section{Pendahuluan}

Kekerasan terhadap perempuan merupakan masalah klasik dan selalu saja terjadi terutama kekerasan didalam rumah tangga. Kekerasan dalam rumah tangga (selanjutnya disebut KDRT) dapat dimaknai sebagai setiap perbuatan terhadap seseorang terutama perempuan yang mengakibatkan timbulnya kesengsaraan atau penderitaan secara fisik, seksual, psikologis, dan/atau penelantaran rumah tangga. Selain itu, perbuatan kekerasan juga dapat berupa ancaman untuk melakukan perbuatan, pemaksaan, atau perampasan kemerdekaan secara melawan hukum dalam lingkup rumah tangga. Kekerasan terhadap perempuan telah menjadi permasalahan penting dan menimbulkan kecemasan di setiap negara di dunia, termasuk negara-negara maju yang dikatakan sangat menghargai hak-hak asasi manusia (selanjutnya disingkat dengan HAM). Fakta menunjukkan bahwa tindak pidana kekerasan terhadap perempuan sebagai pasangan telah memberikan dampak negatif yang cukup besar bagi perempuan sebagai korban. ${ }^{1}$

Fakta yang terjadi di Indonesia, tingkat kekerasan terhadap perempuan dalam rumah tangga semakin meningkat setiap tahunnya, ternyata produk hukum yang melarang tindak kekerasan terhadap perempuan dalam rumah tangga kalah kuat dengan budaya hukum yang selama ini dianut oleh masyarakat. Budaya patriarkhi merupakan salah satu faktor yang menyuburkan kasus kekerasan dalam rumah tangga.

Salah satu budaya terbesar di Indonesia adalah budaya Melayu. Budaya Melayu menyandarkan keseluruhan kaidahnya pada ajaran Islam. Adat bersendi syara', syara' bersendi kitabullah merupakan ketentuan utama yang tidak dapat diubah. Syara' mengatakan adat memakai. Artinya semua ketentuan yang diwajibkan dalam Islam adalah sesuatu yang harus diimplementasikan dalam adat. Bagi adat kebenaran adalah adat. Sedangkan diluar itu bukanlah adat. Kebenaran yang sesungguhnya adalah Al-Quran, yang diperkuat cara implementasinya melalui hadis-hadis. Ini berarti perspektif budaya Melayu terhadap gender tidak akan berbeda dengan perspektif Islam. Pada beberapa wilayah di Riau penempatan perempuan dalam tatanan sosial kemasyarakatan memang mendua. ${ }^{2}$

\footnotetext{
${ }^{1}$ Aroma Elmina Martha, Perempuan dan Kekerasan Dalam Rumah Tangga di Indonesia dan Malaysia, FH UII Press, Yogyakarta, 2012, hlm.2.

${ }^{2}$ Edyanus Herman Halim, Budaya, Agama dan Gender, Jurnal Puanri, Vol. 2 No. 1, Juni 2007, hlm.122.
} 
Kota Batam adalah kota terbesar di Kepulauan Riau dan merupakan kota dengan populasi terbesar ketiga di wilayah Sumatera setelah Medan dan Palembang. Pulau Batam dihuni oleh orang melayu dengan sebutan orang selat sejak 231 Masehi. Pulau yang pernah menjadi medan perjuangan Laksamana Hang Nadim dalam melawan penjajah ini digunakan oleh pemerintah pada dekade 1960-an sebagai basis logistik minyak bumi di Pulau Sambu. Masyarakat kota Batam mayoritas adalah masyarakat melayu yang dekat dengan budaya patriarkhi. Dari beberapa daerah yang masyarakatnya patriarkhi terbukti bahwa banyak terjadi kekerasan dalam rumah tangga, dikarenakan posisi istri yang dianggap lebih rendah dari suami sehingga bisa dilecehkan.

Kota Batam termasuk salah satu provinsi di Indonesia yang cukup tinggi tingkat kejahatannya baik kejahatan perdagangan orang, pembunuhan termasuk Kekerasan Dalam Rumah Tangga. Menurut data yang sudah kami himpun di Polresta Balerang Kota Batam pada 2 Mei 2013, menunjukkan bahwa hampir 95\% pelapor kasus Kekerasan Dalam Rumah Tangga adalah Istri. Berikut tabel di bawah ini:

Tabel 1

Data Pelapor Kasus KDRT di Polresta Balerang Kota Batam (2008-2013)

\begin{tabular}{|l|l|l|l|l|l|l|}
\hline Tahun & \multicolumn{1}{|c|}{ Istri } & \multicolumn{1}{c|}{ PRT } & \multicolumn{1}{c|}{ Anak } & \multicolumn{1}{c|}{ Suami } & \multicolumn{1}{c|}{ Teman } & \multicolumn{1}{c|}{ Jumlah } \\
\hline 2008 & 88 orang & 1 orang & 4 orang & - & - & 93 orang \\
2009 & 61 orang & 1 orang & 28 orang & 6 orang & 4 orang & 100 orang \\
2010 & 35 orang & 5 orang & 17 orang & 10 orang & - & 67 orang \\
2011 & 60 orang & 4 orang & 30 orang & 7 orang & 14 orang & 115 orang \\
2012 & 31 orang & - & - & 1 orang & 2 orang & 34 orang \\
2013 & 9 orang & - & - & - & - & 9 orang \\
\hline
\end{tabular}

Sumber : Polresta Balerang Kota Batam

Pada era reformasi yang sangat menghargai Hak Asasi Manusia, masalah kekerasan terhadap perempuan seharusnya tidak terjadi lagi. Dalam perspektif Hak Asasi Manusia, tindakan diskriminasi terhadap perempuan adalah melanggar HAM. Kenyataannya globalisasi dan individualisme selalu memberi jalan terjadinya tindak kekerasan ini. Pranata-pranata sosial seakan tidak mampu lagi menghambat suburnya praktek Kekerasan Dalam Rumah Tangga.

Maraknya isu kekerasan terhadap perempuan dalam rumah tangga beberapa tahun belakangan ini merupakan cermin tersendatnya pelaksanaan perlindungan hak asasi manusia terhadap perempuan di negeri ini. Indonesia sebagai negara yang 
berdasarkan atas hukum telah berupaya membentuk berbagai instrumen hukum untuk memberikan perlindungan terhadap hak-hak perempuan.

UU PKDRT secara sepintas, sudah bersifat komprehensif dalam pencegahan Kekerasan Dalam Rumah Tangga. Pengenaan sanksi bagi pelaku KDRT sudah sangat berat, dibandingkan dengan pengenaan sanksi dalam KUHP. Namun dalam pelaksanaannya, proses penegakan hukum masih belum berjalan sesuai dengan harapan. Faktor penghambat yang paling utama adalah belum dipahami oleh masyarakat terhadap bahaya dan dampak dari KDRT, karena terisolasi oleh nilainilai budaya yang patriarki dan pemahaman yang salah terhadap teks-teks agama. Demikian juga dari segi korban/calon korban adanya faktor-faktor sistemik yang menjadi penyebabnya. Diantara penyebab tersebut adalah kemiskinan/faktor ekonomi, tingkat pendidikan yang rendah, mindset perempuan sendiri dalam melihat kedudukannya, faktor lingkungan, dan masih banyak faktor lainnya.

Perlindungan hukum terhadap perempuan korban KDRT dan keluarganya memerlukan komitmen yang kuat dengan penghargaan yang tinggi terhadap nilai keadilan, non diskriminasi dan hak asasi manusia sebagaimana telah dijamin oleh konstitusi.

Adanya sistem hukum yang belum bersahabat dengan perkara-perkara KDRT bukan semata karena isi undang-undangnya, namun lebih pada mindset para aparat penegak hukum, aparat pemerintah, dan masyarakat luas yang masih dilingkupi pandangan yang patriarkhis sehingga tindakan-tindakan diskriminatif kerapkali mewarnai pada kehidupan sehari-hari sebagai bukti adanya KDRT terjadi dalam masyarakat. Langkah untuk menuju adanya sistem hukum yang responsif gender masih butuh perjuangan keras melalui pemecahan akar-akar permasalahannya. ${ }^{3}$

\section{Rumusan Masalah}

Adapun permasalahan dalam penelitian ini menunjukkan bahwa, Pertama: bagaimanakah implementasi Undang-Undang Nomor 23 Tahun 2004 tentang Penghapusan Kekerasan Dalam Rumah Tangga di Kota Batam? Kedua, apakah faktor penghambat implementasi Undang-Undang Nomor 23 Tahun 2004 tentang Penghapusan Kekerasan Dalam Rumah Tangga di Kota Batam? Ketiga, bagaimanakah upaya pencegahan kekerasan dalam rumah tangga di Kota Batam?

\footnotetext{
${ }^{3}$ Mudjiati, Hukum Pidana,djpp.depkumham.go.id, diakses 18 Agustus 2010
} 


\section{Tujuan Penelitian}

Adapun tujuan penelitian ini adalah untuk mengetahui: pertama, implementasi Undang-Undang Nomor 23 Tahun 2004 tentang Penghapusan Kekerasan Dalam Rumah Tangga di Kota Batam. Kedua, faktor penghambat implementasi UndangUndang Nomor 23 Tahun 2004 tentang penghapusan kekerasan dalam rumah tangga di Kota Batam. Ketiga, upaya pencegahan kekerasan dalam rumah tangga di Kota Batam.

\section{Metode Penelitian}

Penelitian ini merupakan penelitian hukum sosiologis, berupa studi empiris untuk menemukan teori-teori mengenai proses terjadinya dan mengenai proses bekerjanya hukum dalam masyarakat. ${ }^{4}$ Penelitian dilaksanakan di salah satu Kantor Kepolisian Kota Batam Kepulauan Riau dalam kurun waktu 6 (enam) bulan. Data yang akan digunakan dalam penelitian ini adalah: a) data primer yaitu data yang diperoleh langsung dari responden dengan menggunakan alat pengumpulan data berupa wawancara; $b$ ) data sekunder yaitu data yang diperoleh dari peraturan perundang-undangan dan literatur-literatur yang berhubungan dengan masalah pokok dari penelitian ini; c) data tertier adalah data yang diperoleh melalui kamus, ensiklopedi, dan yang sejenisnya untuk mendukung data primer dan sekunder.

Adapun teknik pengukuran data yang peneliti gunakan sebagai berikut: a) observasi yaitu teknik pengamatan langsung terhadap objek penelitian secara langsung ke lokasi penelitian mengenai Implementasi Undang-Undang Nomor 23 Tahun 2004 tentang Penghapusan Kekerasan Dalam Rumah Tangga di Kota Batam; b ) wawancara, yaitu mengadakan proses tanya jawab langsung kepada responden dengan pertanyaanpertanyaan non struktur yang relevan dengan permasalahan yang sedang diteliti; c) kajian Kepustakaan, yaitu untuk memperlengkap data yang dibutuhkan dalam penelitian ini, peneliti melakukan pengumpulan data dengan literatur kepustakaan yang mempunyai hubungan logis dengan permasalahan yang sedang diteliti. Hal ini dilakukan untuk mencari data sekunder guna sebagai pendukung terhadap data primer.

Metode pengambilan sampel adalah purposive sampling yaitu pengambilan disesuaikan dengan tujuan penelitian, ukuran sampel tidak dipersoalkan, sampel

${ }^{4}$ Bambang Sunggono, Metode Penelitian Hukum, Raja Grafindo Persada, Jakarta, 1996, hlm. 43 
yang diambil hanya yang sesuai dengan tujuan penelitian. ${ }^{5}$ Populasi adalah sekumpulan objek yang akan diteliti. Sedangkan sampel adalah sebagian dari populasi yang dapat mewakili keseluruhan objek penelitian yang mempermudah peneliti dalam menemukan penelitian. Sedangkan untuk kantor Kepolisian Kota Batam Kepulauan Riau menggunakan metode sensus yaitu sampel mengambil keseluruhan dari jumlah populasi. Untuk tercapainya maksud dan tujuan penelitian ini, maka yang menjadi populasi dan sampel dalam penelitian ini adalah:

Tabel 2

Jumlah Populasi dan Sampel

\begin{tabular}{|l|l|c|c|c|}
\hline No & \multicolumn{1}{|c|}{ Responden } & Poulasi & Sampel & Persentase \\
\hline 1 & $\begin{array}{l}\text { Kepala Kepolisian Batam } \\
2\end{array}$ & 1 & 1 & $100 \%$ \\
\hline
\end{tabular}

\section{Hasil Penelitian dan Pembahasan}

\section{Implementasi Undang-Undang Nomor 23 Tahun 2004 tentang Penghapusan} Kekerasan Dalam Rumah Tangga di Kota Batam

Jhon Galtung mendefinisikan kekerasan sebagai “ any avoidable impediment to self realization" jadi kekerasan adalah segala sesuatu yang menyebabkan orang terhalang untuk mengaktualisasikan potensi diri secara wajar. ${ }^{6}$ Hal ini tentu bertentangan dengan konsep HAM, terutama menyangkut personal rights. KDRT merupakan pelanggaran terhadap HAM, dalam hal ini hak asasi perempuan.

DUHAM merupakan standar umum bagi peningkatan penghormatan terhadap hak dan kebebasan manusia agar lebih bermartabat dan dilindungi, yang berlandaskan kepada keadilan, kebebasan serta kedamaian. Setelah DUHAM, lahir berbagai instrumen HAM Internasional yang mengatur kedudukan perempuan dalam kehidupan berkeluarga dan masyarakat, antara lain Konvensi Penghapusan Segala Bentuk Diskriminasi Terhadap Perempuan disebut Konvensi Wanita atau Konvensi Perempuan atau Konvensi Cedaw, yang lahir pada tanggal 18 Desember

${ }^{5}$ Abdulkadir Muhammad, Hukum dan Penelitian Hukum, Citra Aditya Bhakti, Bandung, 2004, hlm. 47.

${ }^{6}$ Lihat Abdullah Muzakkar, Media Massa Dan Kekerasan Terhadap Perempuan, Jurnal Puanri Pekanbaru, Vol.1 No. 2 Desember 2006, hlm. 27 
1979.7 Konvensi Cedaw adalah Konvensi yang paling komprehensif mengatur perlindungan hak-hak perempuan, menekankan pentingnya penghapusan diskriminasi terhadap perempuan dalam segala bentuk dan perwujudannya. Konsep diskriminasi terdapat dalam Pasal $1 .{ }^{8}$ Instrumen hukum lain yang mengatur tentang kedudukan perempuan adalah Deklarasi Penghapusan Kekerasan terhadap Perempuan (Declaration on the Elimination of Violence Against Women) 1993.

Gerakan dan diseminasi hak asasi manusia terus berlangsung bahkan dengan menembus batas-batas teritorial sebuah negara. Begitu derasnya kemauan dan daya desak hak asasi manusia, maka jika ada sebuah negara yang diidentifikasi telah melanggar HAM, dengan sekejap mata nation-state di belahan bumi ini memberikan respons,terlebih beberapa negara yang dijuluki sebagai "adikuasa”, memberikan kritik, tudingan, bahkan kecaman keras seperti embargo dan sebagainya. ${ }^{9}$

Negara Indonesia terus berbenah memperbaiki sistem hukum agar lebih responsif gender, salah satunya dengan mengeluarkan berbagai peraturan hukum yang lebih ramah terhadap kepentingan kaum perempuan. Faktanya perkembangan global yang sangat pesat di bidang emansipasi wanita mengalami benturan dengan nilai-nilai budaya yang telah bertahun-tahun dianut oleh masyarakat.

Selain memiliki landasan konstitusional, penghapusan kekerasan terhadap perempuan juga telah diatur oleh Undang-Undang Republik Indonesia Nomor 23 Tahun 2004 tentang Penghapusan Kekerasan dalam Rumah Tangga (selanjutnya disebut UU PKDRT). UU PKDRT ini merupakan kemajuan nyata yang dihasilkan perjuangan gerakan feminis di Indonesia. KDRT yang selama ini dianggap hanya berada di dalam wilayah privat, kini telah dijadikan sebagai suatu masalah publik. Dalam hal ini dikotomi publik-privat berhasil didekonstruksi. ${ }^{10}$

Tindak kekerasan dalam rumah tangga menunjukkan bahwa bentuk kekerasan ini sangat berhubungan erat dengan persoalan gender, diskriminasi terhadap

${ }^{7}$ CEDAW sebenarnya adalah singkatan dari Committee on the Elimination of Discrimination Against Women, suatu komite PBB yang bertugas memantau implementasi Konvensi Penghapusan Segala Bentuk Diskriminasi Terhadap Perempuan di Negara-negara peserta (negara yang meratifikasi konvensi) dan mengawasi kepatuhan negara-negara tersebut dalam melaksanakan Konvensi Perempuan.

${ }^{8}$ Pasal 1, Konvensi Tentang Penghapusan Segala Bentuk Diskriminasi Terhadap Perempuan (Cedaw), berbunyi: untuk tujuan Konvensi yang sekarang ini, istilah"diskriminasi terhadap perempuan” berarti setiap pembedaan, pengucilan atau pembatasan yang dibuat atas dasar jenis kelamin, yang mempunyai pengaruh atau tujuan untuk mengurangi atau menghapuskan pengakuan, penikmatan atau penggunaan hak-hak asasi manusia dan kebebasankebebasan pokok di bidang politik, ekonomi, sosial, budaya, sipil atau apapun lainnya oleh kaum perempuan, terlepas dari status perkawinan mereka, atas dasar persamaan antara laki-laki dan perempuan.

${ }_{9}^{9}$ A.Masyhur Effendi, Tempat Hak-hak. Asasi Manusia dalam Hukum Internasional/Nasional, Alumni, Bandung, 1980, hlm. 17.

${ }^{10}$ Ester Lianawati, Tiada Keadilan Tampa Kepedulian KDRT, Paradigma Indonesia, Yogyakarta, 2009, hlm.1-2. 
perempuan dan kuatnya budaya yang dianut masyarakat bahwa persoalan rumah tangga adalah masalah privat dan hanya merupakan ekses dari dinamisasi kehidupan rumah tangga.

Pada awalnya kekerasan terhadap perempuan tidak ubahnya sebagaimana kejahatan konvensional lainnya, tidak ditempatkan sebagai kejahatan berkarakter khas yaitu spesifikasi pada korban dengan jenis kelamin perempuan serta mempunyai dampak yang khas pula, baik secara khusus pada diri korban maupun secara umum pada aspek sosial masyarakat. Lebih dari itu bahkan tidak ada perlakuan khusus terhadap perempuan sebagai korban yang mengalami dampak atas perilaku kekerasan yang menimpanya itu. Kini hukum lebih responsif dan akomodatif terhadap perkembangan pemahaman kompleksitas bentuk dan dampak dari kejahatan yang tertuju pada perempuan sebagai korbannya, sehingga dikenal sebutan kekerasan terhadap perempuan. ${ }^{11}$

Kekerasan terhadap perempuan adalah merupakan kejahatan kemanusiaan karena selain melanggar hak asasi manusia juga menimbulkan dampak yang sangat besar baik bagi kelangsungan kehidupan perempuan itu sendiri dan juga bagi masa depan generasi penerus bangsa, karena perempuan merupakan salah satu aset bangsa. Tindak kekerasan merupakan pelanggaran hukum, pelanggaran terhadap norma agama dan norma sosial. Seksualitas perempuan dan anak perempuan rentan terhadap perlakuan diskriminatif dan kekerasan. Bila bicara tentang kekerasan dalam rumah tangga, perempuan bahkan mengalami tindak kekerasan didalam rumahnya sendiri. Hampir tidak dapat dipercayai bahwa pelaku kekerasan adalah orang yang justru dicintai dan dipercayai untuk menjaganya: ayah,suami, paman, kerabat dan orang-orang di dalam rumah sendiri.

Dalam hal terjadinya kekerasan oleh pelaku tersebut, ternyata bahwa hubungan cinta dan kepercayaan itu seringkali merupakan mitos saja. Laporan yang datang dari berbagai penjuru dunia mencatat bahwa kekerasan dalam rumah tangga terjadi di segala lapisan masyarakat. Pelaku dan korban berasal dari berbagai suku bangsa, ras, agama, kelas sosial dan tingkat pendidikan yang manapun.

Nilai-nilai sosial budaya yang memarginalkan dan mensubordinasikan kaum perempuan, juga memperparah kondisi ini. Hubungan yang sub-ordinasi tersebut dialami oleh kaum perempuan diseluruh dunia karena hubungan yang sub-ordinasi

\footnotetext{
${ }^{11}$ M.Munandar Sulaeman dan Siti Homzah, Kekerasan Terhadap Perempuan (Tinjauan dalam Berbagai Disiplin Ilmu dan Kasus Kekerasan), Refika Aditama, Bandung, 2010, hlm.78
} 
tidak saja dialami oleh masyarakat yang sedang berkembang seperti masyarakat Indonesia, namun juga dialami oleh masyarakat negara-negara yang sudah maju seperti Amerika Serikat dan lain-lain. ${ }^{12}$ Kondisi kemiskinan yang dialami oleh perempuan bukanlah disebabkan karena faktor bahwa perempuan lebih malas dibandingkan laki-laki, akan tetapi kemiskinan kelompok perempuan lebih banyak disebabkan oleh faktor-faktor struktural yang menghegemoni dan membonsai peranperan perempuan, sehingga posisi perempuan menjadi lemah dan miskin. ${ }^{13}$ Disamping itu juga terjadi perubahan dalam adat istiadat dan moral masyarakat. Pengaruh industrialisasi yang menonjol terdapat pada status pekerjaan dan keahlian bekerja, terhadap kehidupan keluarga dan kedudukan wanita, serta tradisi dan kebiasaan dalam mengkonsumsi barang. ${ }^{14}$

Sikap tradisional bahwa perempuan dianggap sebagai subordinasi laki-laki, pembakuan peran-peran stereotipe, disertai dengan sikap tradisional perempuan seperti kebergantungan sosial dan ekonomi pada suami dan keluarga serta rasa takut dan keengganan perempuan korban kekerasan untuk mendapatkan keadilan, merupakan sebab-sebab utama diantara sekian sebab lainnya yang menyebabkan bahwa tindak kekerasan dalam rumah tangga tidak terungkap atau tidak diatasi. Sikap tradisional yang mengganggap bahwa apa yang terjadi dalam rumah tangga merupakan hal-hal yang sebaiknya diselesaikan dalam rumah tangga pula. Disertai dengan keterbatasan peraturan perundang-undangan yang dapat digunakan untuk menyelesaikan tindak kekerasan dalam rumah tangga melalui jalur hukum, mulai dari proses pelaporan yang berbelit-belit, proses penyelidikan dan penyidikan serta pengajuan ke pengadilan, dan proses peradilan di pengadilan, merupakan pula sebab-sebab mengapa tidak banyak korban mengadu ke penegak hukum. Masih langkanya women's crisis centre dan ketidaktahuan korban tentang lembaga yang dapat membantunya mengatasi masalahnya, merupakan pula sebab bahwa korban memilih untuk mendiamkannya. ${ }^{15}$

Kehadiran Undang-Undang Nomor 23 Tahun 2004 tentang Penghapusan Kekerasan Dalam Rumah Tangga membuka jalan bagi terungkapnya kasus KDRT

\footnotetext{
${ }^{12}$ Abdul Rahmad, Gender Dalam Hukum Adat, Normative, Vol.1, No.10, Juni 2009, hlm.73.

${ }^{13}$ Abdullah Muzakkar, Perempuan dan Kemiskinan;Realitas Ketidak. Adilan Gender, Puanri, Vol.2, No.2, Desember 2007, hlm. 35.

${ }^{14}$ Ismail Fahmi Arrauf, Menimbang Peran Agama Dalam Masyarakat Modern dan Industri, Industri dan Perkotaan, Vol. 14, No. 26, Agustus 2010, hlm. 156

15 Achie Sudiarti Luhulima, Pemahaman Bentuk-Bentuk. Tindak Kekerasan Terbadap Perempuan dan Alternatif Pemecahannya, PT.Alumni, Bandung, 2000, hlm.140.
} 
dan memberikan upaya perlindungan hak-hak korban. Dimana, awalnya KDRT dianggap sebagai wilayah privat yang tidak boleh seorang pun diluar lingkungan rumah tangga dapat memasukinya.

Undang-Undang Nomor 23 Tahun 2004 tentang Penghapusan Kekerasan Dalam Rumah Tangga merupakan hukum publik yang didalamnya ada ancaman pidana penjara atau denda bagi yang melanggarnya, maka masyarakat luas khususnya kaum laki-laki, dalam kedudukan sebagai kepala keluarga sebaiknya mengetahui apa itu Kekerasan Dalam Rumah Tangga (KDRT).

Latar belakang kehadiran Undang-Undang ini dimaksudkan untuk memberikan efek jera bagi pelaku KDRT, ancaman hukuman yang tidak mencantumkan hukuman minimal dan hanya hukuman maksimal sehingga berupa ancaman hukum alternatif kurungan atau denda terasa terlalu ringan bila dibandingkan dengan dampak yang diterima korban, bahkan lebih menguntungkan bila menggunakan ketentuan hukum sebagaimana diatur dalam KUHP. Dalam pelaksanaan Undang-Undang ini perlu adanya upaya strategis diluar diri korban guna mendukung dan memberikan perlindungan bagi korban dalam rangka mengungkapkan kasus KDRT yang menimpanya.

Dalam Undang-Undang Nomor 23 Tahun 2004 tentang Penghapusan Kekerasan Dalam Rumah Tangga menyatakan bahwa penghapusan kekerasan dalam rumah tangga tidak hanya menjadi tanggung jawab negara, tetapi masyarakat juga berkewajiban untuk melindungi korban. Satu hal yang juga dianggap terobosan hukum adalah masalah pembuktian yang mendasarkan pada kesaksian korban serta adanya perintah perlindungan korban.

Pada umumnya Undang-Undang Nomor 23 Tahun 2004 tentang Penghapusan Kekerasan Dalam Rumah Tangga, bukan hanya ditujukan kepada seorang suami, tapi juga bisa ditujukan kepada seorang istri yang melakukan kekerasan terhadap suaminya, anak-anaknya, keluarganya atau pembantunya yang menetap tinggal dalam satu rumah tangga.

Dampak terhadap Undang-Undang Nomor 23 Tahun 2004 tentang Penghapusan Kekerasan Dalam Rumah Tangga di Kota Batam tiap tahunnya bersifat fluktuatif. Hal ini dapat dilihat dari hasil data jumlah pelapor kasus KDRT yang peneliti peroleh dari Polresta Balerang Kota Batam dari 2008-Mei 2013. 


\section{Grafik: Jumlah Pelapor Kasus KDRT di Polresta Balerang Kota Batam dari Tahun 2008-Mei 2013 (sumber: Polresta Balerang Kota Batam)}

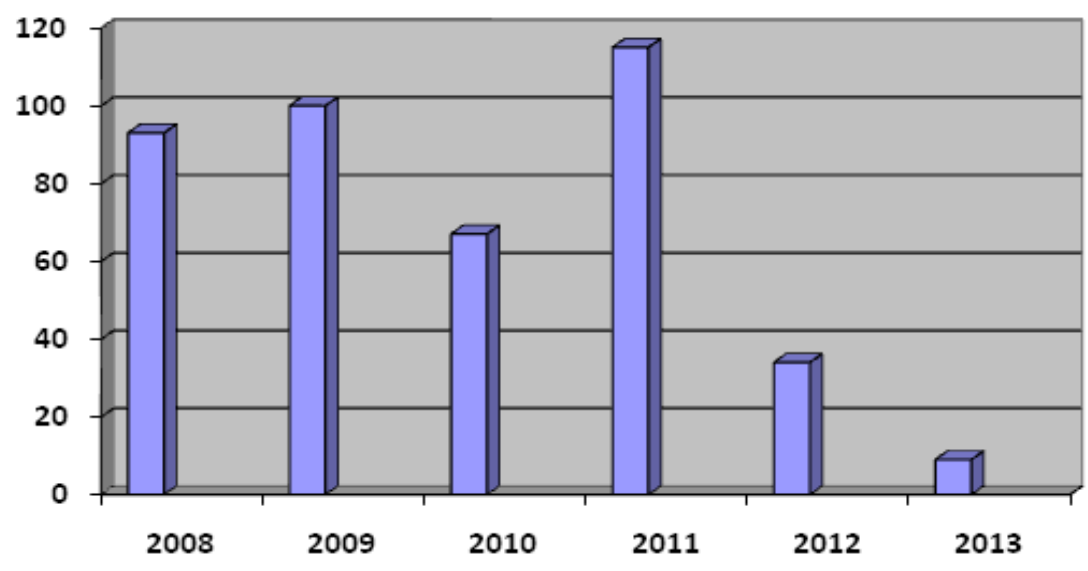

Berdasarkan grafik tersebut di atas memberikan gambaran kepada penulis bahwa masih kurangnya tingkat kesadaran masyarakat terhadap kehadiran UndangUndang Nomor 23 Tahun 2004 tentang Penghapusan Kekerasan Dalam Rumah Tangga di Kota Batam. Hal ini bisa saja terjadi dikarenakan masih belum efektifnya sosialisasi terhadap Undang-Undang Nomor 23 Tahun 2004 tentang Penghapusan Kekerasan Dalam Rumah Tangga oleh pemerintah Batam.

Selain itu, berdasarkan hasil kuisioner yang sudah peneliti sebarkan ke beberapa sejumlah masyarakat di Kota Batam, 44 orang dari 50 orang mengatakan bahwa belum ada sosialisasi yang dilakukan oleh Pemerintah Kota Batam terhadap Undang-Undang Nomor 23 Tahun 2004 tentang Penghapusan Kekerasan Dalam Rumah Tangga. Alasan yang mereka paparkan dikarenakan kurangnya minat masyarakat dan kurangnya sensitivitas jender dan kepekaan dilingkungan kota Batam terhadap kasus KDRT. ${ }^{16}$

Penulis menyimpulkan bahwa implementasi Undang-Undang Nomor 23 Tahun 2004 tentang Penghapusan Kekerasan Dalam Rumah Tangga mendorong dan mengharuskan adanya rekonstruksi fundamental dalam tatanan birokrasi. Peran elemen hukum justru berposisi dalam konteks wajib, sebagaimana disebutkan dalam Bab 6 Pasal 11 yaitu: Pemerintah bertanggung jawab dalam upaya pencegahan kekerasan dalam rumah tangga.

Rekonstruksi kebudayaan yang didorong Undang-Undang Nomor 23 Tahun 2004 tentang Penghapusan Kekerasan Dalam Rumah Tangga adalah pemaknaan

\footnotetext{
${ }^{16}$ Hasil kuisioner penelitian
} 
ulang tentang keluarga yang selama ini dipandang sebagai institusi tak tersentuh dalam hal relasi suami-istri-anak dan pekerja rumah tangga. Ada transformasi pemahaman secara fundamental, urusan-urusan yang selama ini dianggap privat dan tersimpan rapi, diluluhlantakkan Undang-Undang Nomor 23 Tahun 2004 tentang Penghapusan Kekerasan Dalam Rumah Tangga menjadi persoalan publik.

\section{Faktor Penghambat Implementasi Undang-Undang Nomor 23 Tahun 2004 tentang} Penghapusan Kekerasan Dalam Rumah Tangga di Kota Batam

Banyak tantangan yang dihadapi oleh Pemerintah Kota Batam dalam hal pelaksanaan Undang-Undang Nomor 23 Tahun 2004 tentang Penghapusan Kekerasan Dalam Rumah Tangga di Kota Batam, yaitu: pertama, pola pikir yang konvensional. Dalam membangun pola kesadaran akan eksistensi masyarakat sebagai subyek hukum, karena sebagian besar masyarakat di Kota Batam masih setia pada pola fikir yang konvensional. Pola pikir yang konvensional tersebut adalah cara berfikir yang melihat bahwa ranah rumah tangga sebagai wilayah otoritarian privat, sehingga hukum publik dianggap tidak bisa turut campur terhadap apapun yang terjadi di dalamnya. Kedua, budaya patriliakat. Mayoritas pendudukan yang beragama Islam, penafsiran agama dan budaya yang salah dan masih kentalnya nilai-nilai kebudayaan dalam tatanan sosial penduduk Batam, sehingga perempuanperempuan yang sudah bersuami, berfikir bahwa sudah kewajiban mereka untuk menjaga setiap aib keluarga, aib suami dan merasa bahwa sah-sah saja terhadap apa yang dilakukan suami kepadanya. Budaya ini juga menempatkan laki-laki sebagai superioritas di berbagai bidang, termasuk dalam rumah tangga. Ketiga, kurangnya sosialisasi. Kurangnya sosialisasi substansi Undang-Undang Penghapusan Kekerasan Dalam Rumah Tangga di kalangan para aparat penegak hukum. Sudah lazim dialami kesulitan-kesulitan dalam penggunaan suatu produk Undang-Undang yang disebabkan ketidaktahuan aparat akan Undang-Undang tersebut. Keempat, tidak ada perangkat hukum. Secara struktural belum adanya perangkat hukum yang secara khusus dijadikan rujukan hukum. Selama ini dalam menyelesaikan kasus KDRT, instrumen yang dipakai adalah Undang-Undang perkawinan, yang tidak sesuai dan tidak akomodatif, karena secara tegas tidak mampu mendefenisikan KDRT sebagai sebuah kejahatan kriminal tertentu oleh Undang-Undang. Kelima, pernikahan yang belum sah secara hukum. Selain ke-empat faktor penghambat tersebut, ada faktor lain yang menyulitkan bagi korban KDRT 
untuk mengakses layanan hukum. Hal ini disebabkan status perkawinan klien yang masih banyak belum sah secara hukum.

\section{Upaya Pencegahan Kekerasan Dalam Rumah Tangga di Kota Batam}

Menguatnya upaya untuk penghapusan kekerasan terhadap perempuan melalui pendekatan struktural memang harus tetap dilakukan, agar kebijakankebijakan publik bisa menjadi lebih responsif terhadap kondisi dan posisi perempuan. Pemikiran mengenai kekerasan terhadap perempuan bukanlah persoalan yang ditimbulkan oleh unsur individual, melainkan bersifat sistemik dan struktural.

Dalam Undang-Undang Nomor 23 Tahun 2004 tentang Penghapusan Kekerasan Dalam Rumah Tangga, Pemerintah mempunyai kewajiban, yaitu: a) merumuskan kebijakan penghapusan KDRT; b) menyelenggarakan komunikasi, informasi dan edukasi tentang KDRT; c) menyelenggarakan sosialisasi dan advokasi tentang KDRT; dan d) menyelenggarakan pendidikan dan pelatihan sensitif jender, dan isu KDRT serta menetapkan standar dan akreditasi pelayanan yang sensitif jender.

Hasil wawancara penulis dengan Brigadir Lesly D.L. (Unit PPA SAT RESKRIM), Pemerintah Kota Batam sudah melaksanakan kegiatan-kegiatan yang berkaitan dengan upaya pencegahan kekerasan dalam rumah tangga di Kota Batam, yaitu: 1) kampanye media. Salah satu upaya pencegahan yang dilakukan oleh Pemerintah Kota Batam dimulai dengan mengembangkan strategi media untuk membangun kesadaran publik berkaitan dengan perluasan pemahaman, dampak, dan konsekuensi sosial yang harus diterima tidak saja oleh perempuan dan anak perempuan, melainkan juga seluruh umat manusia. Iklan Layanan Masyarakat (ILM) ini disiarkan melalui stasiun televisi lokal, yaitu Batam TV. Selain itu juga media Radio juga turut mengumandangkan Iklan Layanan Masyarakat ini. Selain itu media massa, cetak atau elektronik juga dimanfaatkan oleh Pemerintah untuk mengupayakan sosialisasi Undang-Undang tersebut; 2) sosialisasi. Selain dari kampanye media, upaya lain yang dilakukan oleh pemerintah adalah sosialisasi terhadap kehadiran Undang-Undang Nomor 23 Tahun 2004 tentang Penghapusan Kekerasan Dalam Rumah Tangga di tingkat Kecamatan dan Kelurahan. Pelaksanaan sosialisasi ini bekerja sama dengan beberapa Lembaga Swadaya Masyarakat (LSM) yang ada di Kota Batam. Sosialisasi tersebut sering dilaksanakan pada acara Majlis Taklim di mesjid-mesjid dan ketika acara PKK. 
Selanjutnya Brigadir Lesly. D.L mengatakan: “Sosialisasi yang dilakukan oleh Pemerintah Kota Batam bertujuan untuk memberikan konsultasi dan advokasi bagi masyarakat mengenai cara-cara pencegahan terjadingan KDRT, mengutamakan peningkatan pengetahuan dan kesadaran kehidupan rumah tangga yang sehat melalui penyuluhan dan sosialisasi Undang-Undang Nomor 23 Tahun 2004 tentang penghapusan Kekerasan Dalam Rumah Tangga. Selain itu juga memfasilitasi kalangan profesi maupun akademisi untuk secara berkelanjutan mengadakan kajian-kajian ilmiah di bidang hukum, khususnya yang berkaitan dengan Penghapusan KDRT." Brigadir Lesly. D.L menyadari bahwa upaya sosialisasi yang dilakukan tersebut masih belum maksimal, selain faktor aparat hukum yang masih belum faham terhadap norma-norma dalam UU KDRT juga permasalahan waktu yang sering menggagalkan acara sosialisasi ini.3) pelatihan pencegahan kekerasan melalui pendidikan keluarga. Bekerja sama dengan Badan Pemberdayaan Perempuan Keluarga Berencana melakukan pelatihan Pencegahan Kekerasan melalui Pendidikan Keluarga di Batam. Tujuan dari pelatihan ini diharapkan kepada peserta untuk dapat menjadi perpanjangan tangan pemerintah dalam upaya meningkatkan peran penting keluarga guna pencegahan kekerasan terhadap perempuan; 4) kebijakan-kebijakan. UndangUndang Nomor 23 Tahun 2004 tentang penghapusan Kekerasan Dalam Rumah Tangga dijadikan acuan oleh aparat Pemerintah Daerah Kota Batam dalam pembuatan kebijakan-kebijakan di tingkat daerah, yang bertujuan untuk melindungi perempuan.

\section{Penutup}

Berdasarkan uraian di atas dapat disimpulkan bahwa; Pertama, implementasi Undang-Undang Nomor 23 Tahun 2004 tentang Penghapusan Kekerasan Dalam Rumah Tangga di Kota Batam belum maksimal, dikarenakan kurangnya kepekaan gender baik oleh masyarakat Batam maupun aparat pemerintah, yang berakibat kurangnya perlindungan hak asasi perempuan korban KDRT. Negara melalui pemerintah Kota Batam harus lebih berperan aktif untuk melaksanakan amanat Undang-Undang PKDRT ini. Undang-Undang PKDRT secara tegas menyatakan bahwa KDRT adalah merupakan bentuk kejahatan terhadap HAM. Perlindungan HAM merupakan sebuah kewajiban dalam suatu Negara Hukum dan merupakan tanggung jawab pemerintah untuk melaksanakannya baik secara de jure maupun secara de facto; Kedua, faktor penghambat implementasi Undang-Undang Nomor 23 
Tahun 2004 tentang penghapusan Kekerasan Dalam Rumah Tangga di Kota Batam adalah terletak pada faktor budaya masyarakat, yaitu pola fikir yang konvensional yang masih kuat dengan budaya patriarkhi, bahwa laki-laki mempunyai strata sosial yang lebih tinggi dari perempuan. Perempuan atau istri harus menurut atau menerima apa saja perlakuan dari laki-laki atau suaminya dengan alasan untuk kehormatan rumah tangga, walaupun dengan mengorbankan hak-hak dasarnya. Ekses dari faktor budaya ini juga, berakibat pada kurang gencarnya sosialisasi tentang Undang-Undang ini, karena pemahaman bahwa KDRT merupakan masalah privat/ keluarga yang tidak dipandang penting; Ketiga, upaya yang sudah dilakukan oleh Pemerintah Kota Batam adalah melakukan kampanye media, sosialisasi Undang-Undang PKDRT, mengadakan Pelatihan Pencegahan Kekerasan melalui Pendidikan Keluarga, serta mengeluarkan beberapa kebijakan-kebijakan.

Adapun saran yang dapat penulis berikan dalam penelitian ini adalah: Pertama, diperlukan sistem Peradilan Pidana terpadu yang berkeadilan gender dalam penanganan kasus kekerasan terhadap perempuan. Sistem ini pada dasarnya sebuah konsep yang disusun untuk dapat dilaksanakan dalam rangka merespon situasi yang senantiasa dialami oleh perempuan korban kekerasan yang berbasis gender. Hal ini akan menjadi terobosan untuk mengubah sistem hukum yang tidak berspektif gender menjadi berspektif gender; Kedua, karena salah satu faktor penghambat implementasi UU PKDRT ini adalah budaya masyarakat, diharapkan kepada Pemerintah Kota Batam untuk memasukkan materi tentang pemahaman Gender pada sistem pendidikan formal.

\section{Daftar Pustaka}

Amiruddin dan Zainal Azikin, Pengantar Metode Penelitian Hukum, Rajagrafindo Persada, Jakarta, 2008. Bandingkan juga dengan Peter Mahmud Marzuki, Penelitian Hukum, Prenada Media, Jakarta, 2005.

E. Fernando, M. Manullang, Menggapai Hukum Berkeadilan, Kompas, Jakarta, 2007.

Effendi, A. Masyhur, Tempat Hak-hak Asasi Manusia dalam Hukum Internasional/Nasional, Alumni, Bandung, 1980.

Fahmi Arrauf, Ismail, Menimbang Peran Agama Dalam Masyarakat Modern dan Industri, Industri dan Perkotaan, Vol. 14, No. 26, Agustus 2010

Herman Halim, Edyanus, Budaya, Agama Dan Gender, Jurnal Puanri, Vol. 2 No. 1, Juni 2007 
Lianawati, Ester, Tiada Keadilan Tanpa Kepedulian KDRT, Paradigma Indonesia, Yogyakarta, 2009.

Luhulima, Achie Sudiarti, Pemahaman Bentuk-Bentuk Tindak Kekerasan Terhadap Perempuan dan Alternatif Pemecahannya, PT.Alumni, Bandung, 2000.

Martha, Aroma Elmina, Perempuan Dan Kekerasan Dalam Rumah Tangga Di Indonesia Dan Malaysia, FH UII Pers, Yogyakarta, 2012.

Mudjiati, Hukum Pidana,djpp.depkumham.go.id, 18 Agustus 2010.

Muhammad, Abdulkadir, Hukum dan Penelitian Hukum, Citra Aditya Bhakti, Bandung, 2004.

Muzakkar, Abdullah, Perempuan dan Kemiskinan;Realitas Ketidak Adilan Gender, Jurnal Puanri, Vol. 2, No. 2, Desember 2007.

Nasution, Bahder Johan, Metode Penelitian Hukum, Mandar Maju, Bandung, 2008.

Rahmad, Abdul, Gender Dalam Hukum Adat, Normative, Vol. 1, No. 10, Juni 2009

Soekanto, Soerjono dan Sri Mamudji, Penelitian Hukum Normatif, Raja Grafindo Persada, Jakarta, 1985.

Sulaeman, M. Munandar dan Siti Homzah, Kekerasan Terhadap Perempuan (Tinjauan dalam Berbagai Disiplin Ilmu dan Kasus Kekerasan), Refika Aditama, Bandung, 2010.

Sunggono, Bambang, Metode Penelitian Hukum, Raja Grafindo Persada, Jakarta, 1996.

Undang-Undang Nomor 23 Tahun 2014 tentang Penghapusan Kekerasan Dalam Rumah Tangga 